\title{
Silent Somatotropic Adenoma and Pregnancy: About A Case
}

\author{
Sara askaoui ${ }^{1 *}$, Guizlane el mghari ${ }^{1}$, Maria Dref ${ }^{2}$, Sana Rafi $^{1}$, Hanane Raiss ${ }^{2}$ and Nawal el ansari ${ }^{1}$ \\ ${ }^{1}$ Department of Endocrinology, Diabetology and Metabolic Diseases, University Hospital of marrakech, Morocco \\ ${ }^{2}$ Department of Pathology, University Hospital of marrakech, Morocco
}

Submission: August 25, 2018; Published: December 06, 2018

*Corresponding author: Sara askaoui, Department of Endocrinology, Diabetology and Metabolic Diseases, University Hospital of marrakech, Imm Dalia 2 c, №18, Albadii, amerchich, Marrakech, Maroc Morocco

\begin{abstract}
Somatotropic adenomas are classically a source of hypersecretion of growth hormone $(\mathrm{GH})$ and consequently of insulin growth factor 1 (IGF1) and responsible of the clinical signs of acromegaly. Rarely, these adenomas remain "silent", without any obvious clinical manifestation. They can then be screened on the basis of a systematic assay of growth hormone under oral glucose tolerance test (GH/ OGTT) and IGF1 or can be diagnosed only in the immunohistochemical study as in the case of a patient we report and the evolution of her disease during pregnancy.

Keywords: Silent somatotropic adenoma; Hyperprolactinemia; Immunohistochemistry; IGF1; Pregnancy; Gestational diabetes

Abbreviations: GH: Growth Hormone; OGTT: Oral Glucose Tolerance Test; MRI: Magnetic Resonance Imagery
\end{abstract}

\section{Introduction}

Silent somatotropic adenomas correspond to a rare entity. Their diagnosis is based on screening by the systematic determination of GH under oral glucose tolerance test (OGTT) and insulin growth factor 1 or the immunohistochemical study, in the absence of clinical signs of acromegaly [1,2]. Pregnancy in acromegalic women is an exception. Data from the literature report the absence of fetal malformation, an increase in adenomatous volume that is rarely symptomatic, a possible risk of gestational diabetes and gestational hypertension in women not controlled by pre-pregnancy drug therapy [3,4]. Variations in somatotropic function have rarely been studied. The aim of this work is to report the case of pregnancy in a patient followed for a silent somatotropic adenoma.

\section{Case Report}

A33-year-old patient who was seen for secondary amenorrhea with anamnesis: asthenia, frontal headache, and galactorrhea. The clinical examination did not indicate a dysmorphic syndrome, noted the presence of multipored galactorrhea caused. The results of the hypophysiogram were as follows:

- $\quad$ Prolactin: $153 \mathrm{ng} / \mathrm{ml}$,

- $\quad$ TSHus: $1.2 \mathrm{mUI} / \mathrm{l}, \mathrm{T} 4 \mathrm{~L}: 9 \mathrm{pmol} / \mathrm{l}(12-22)$,

- $\quad$ FSH: $1.3 \mathrm{UI} / \mathrm{L}, \mathrm{LH}:$ 0,9 UI/L and

- $\quad$ Oestradiol: 9pmol/l.

The somatotropic axis has not been explored.
Pituitary magnetic resonance imagery (MRI) revealed a pituitary macro-adenoma of $18 * 13^{*} 16 \mathrm{~mm}$, repressing the optic chiasm and cavernous sinuses (Figure 1), with the visual field: an enlargement of the blind spot with an amputation of the infero-nasal area of the left eye. The adenoma was treated by cabergoline $10 \mathrm{mg}$ per week for one year with substitution of thyrotropic deficiency. The evolution at one year was marked by the persistence of the latter, with a control prolactinemia at 0,22 $\mathrm{ng} / \mathrm{ml}$. The controlled pituitary MRI noted an increase (by 17\%) of the tumor volume: $21 * 19 * 15.3 \mathrm{~mm}$, with a visual field always altered.

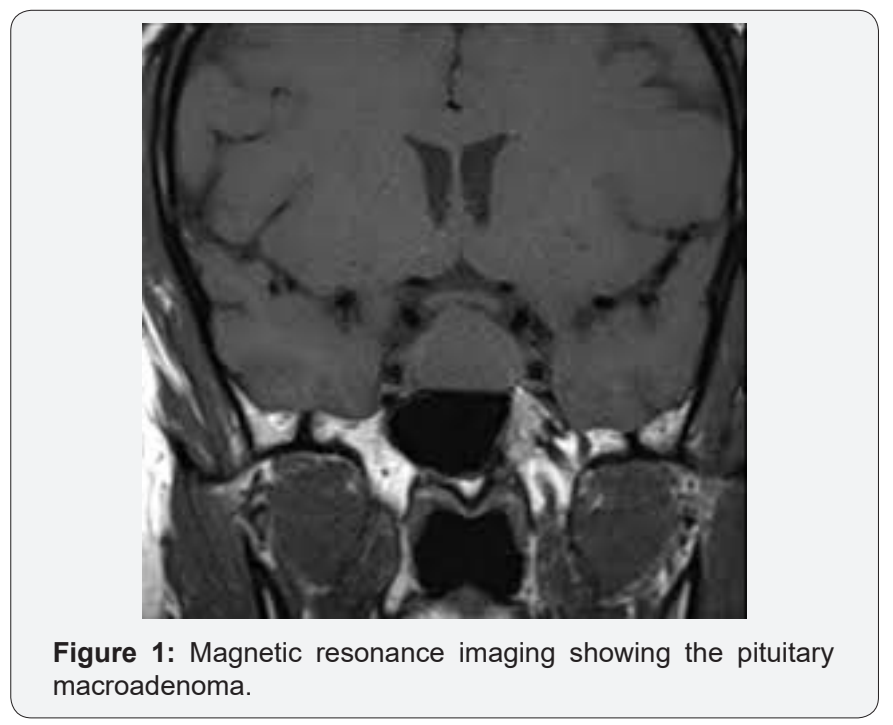




\section{Global Journal of Reproductive Medicine}

An echo-heart was requested as part of the follow-up, further, to increase the dose of cabergoline which revealed the presence of an average tricuspid insufficiency. The latter was declared at the pharmacovigilance center, then, the indication for transphenoidal surgery was raised. The consistency of the tumor was fibrous and haemorrhagic making it impossible to extract. Immunohistochemical analysis returned to a typical somatotropic adenoma (Ki $67<3 \%$, P53 not done) (Figure 2).

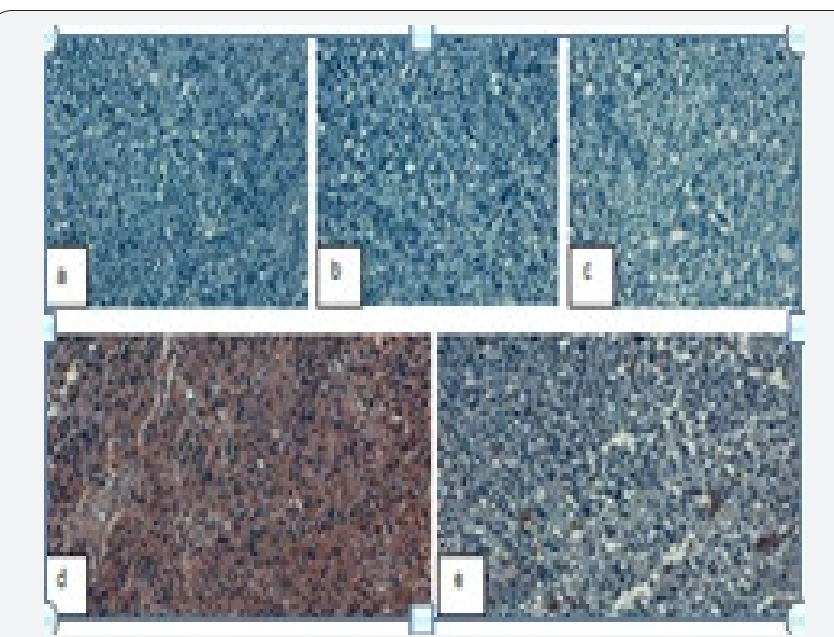

Figure 2: d: positive immuno-labeling alone at GH (a: ACTH, b: $\mathrm{FSH}, \mathrm{c}: \mathrm{TSH}$, e: Prolactine).

Pituitary MRI for control at 3 months post-operative showed constant tumor volume with some necrosis areas with IGF1 at 131ug/l (112-300). The patient was seen after being pregnant at 19 weeks; whose follow-up did not indicate gestational diabetes, nor gravid arterial hypertension, nor signs of intracranial hypertension, nor fetal malformation. Radiological control at 3 months of the postpartum, showed the stability of the tumoral volume with a level of IGF1 always normal. Surgical revision was indicated with supplemental treatment with somatostatin analogues.

\section{Discussion}

The somatotropic adenomas are often identified because of the clinical consequences they cause (dysmorphism). Occasional cases of subclinical adenomas have been described in the literature, where only pathological examination reveals a positive immuno-labeling for GH (somatotropic, cortico-somatotropic and somato-thyrotropic) [5].

Their frequency is poorly studied [6], because in the absence of immune-histochemical study, a nonfunctional adenoma is concluded and IGF1 is not carried out as part of the follow-up; all this leads to a delay in diagnosis, which later gives rise to dysmorphism with the various complications of hypersecretion of GH [7]. For this, a preoperative evaluation of the concentrations of GH / OGTT and IGF-1 is of interest, in addition to the complete histopathological analysis: immunohistochemistry of $\mathrm{GH}$, prolactine, expression of somatostatin receptors and evaluation of proliferation (number of mitoses, Ki-67 index and p53 expression). The treatment of this type of adenoma is initially based on surgery, then somatostatin analogues and lastly on temozolamide and radiotherapy in case of signs of aggression $[8,9]$.

Pregnancies in these patients treated for acromegaly are often not accompanied by obstetric or fetal complications, but a maternal follow-up is necessary in order to diagnose gravid hypertension and gestational diabetes. On the other hand, a clinical monitoring of pituitary tumor syndrome is necessary in women with nonoperated GH macroadenoma before pregnancy [10].

\section{Conclusion}

Silent somatotropic adenoma is a distinct entity from the usual cases of acromegaly, as it may be a beginning of the disease, or a benign aspect of the disease. The systematic implementation of the GH / OGTT and IGF1 preoperatively associated with the immunohistochemical study is of great interest, allowing the screening of this entity and ensuring appropriate monitoring. Clinical monitoring of pituitary tumor syndrome is necessary in pregnant women with non-operated GH macroadenoma.

\section{References}

1. Delcourt Irthum B, Moreau A (2005) Adénome somatotrope silencieux : quand y penser? Annales d'Endocrinologie 66(5) : 454-455.

2. Topolinski H, Kmiha El Hadj H, Vanhove H, Gillot C, Defrance F, et al. (2015) Macroadénome somatotrope silencieux. Annales d'Endocrinologie 76(4): 394.

3. El khadir S, Marhari H, El Ouahabi H (2017) Adénomes hypophysaires et grossesse : à propos de 4 observations. Annales d'Endocrinologie 78(4): 320-321.

4. Persechini ML, Gennero I, Grunenwald S, Vezzosi D, Caron P (2014) Acromégalie et grossesse: six nouvelles observations. Journal de Gynécologie Obstétrique et Biologie de la Reproduction 43: 704-712.

5. Chinezu L, Jouanneau E, Vasiljevic A, Trouillas J, GéraldRaverot G (2013) Silent GH pituitary tumor: Diagnostic and therapeutic challenges. Annales d'Endocrinologie 74(5-6): 491-495.

6. Wade AN, Baccon J, Grady MS, Judy KD, O’Rourke DM, et al. (2012) Clinically silent somatotroph adenomas are common. Eur J Endocrinol 165(1): 39-44.

7. Pagesy P, Li JY, Kujas M, Peillon F, Delalande O, et al. (1999) Apparently Silent Somatotroph Adenomas. Pathology - Research and Practice 187(8): 950-956.

8. khochtali I, Bihan H, Thuminger O (2005) Adénomes somatotropes silencieux : efficacité anti-tumorale des analogues de la somatostatine à propos de deux cas...Annales d'Endocrinologie 66: 455.

9. Ghazi AA, Rotondo F, Kovacs K, Amirbaigloo A, Syro LV, et al. (2015) Treatment of Invasive Silent Somatotroph Pituitary Adenoma with Temozolomide. Report of a Case. Endocr Pathol 26(2): 135-139.

10. Caron P (2011) Acromegaly ans pregnancy. Annales d'Endocrinologie 72: 282-286. 
(C) This work is licensed under Creative

C. Commons Attribution 4.0 License
DOI: $10.19080 /$ GJORM.2018.06.555687

Your next submission with Juniper Publishers
will reach you the below assets
- Quality Editorial service
- Swift Peer Review
- Reprints availability
- E-prints Service
- Manuscript Podcast for convenient understanding
- Global attainment for your research
- Manuscript accessibility in different formats
( Pdf, E-pub, Full Text, Audio)
- Unceasing customer service
Track the below URL for one-step submission
https://juniperpublishers.com/online-submission.php

